\title{
The Hybrid Manager: Achievement within a World-Wide Dimension
}

\author{
J.B. Thompson and H.M. Edwards \\ School of Computing and Information Systems, \\ University of Sunderland \\ Priestman Building, Green Terrace, Sunderland SR1 3PZ \\ Tel: (44) 1915152769, Fax: (44) 1915152781 \\ email: \{barrie.thompson, helen.edwards\}@sunderland.ac.uk
}

\begin{abstract}
The concept of hybrid managers and the need for them is outlined. The provision of hybrid managers with IT skills by means of "conversion type M.Sc. courses" is discussed and the development and operation of such a course by the University of Sunderland is described. This course is particularly innovative in that it operates in four distinct modes at Sunderland and a distance learning mode elsewhere in the UK and also at sites overseas. Case studies are presented of students who have become true hybrid managers following their successful completion of the course. Finally guidelines are proposed regarding the knowledge, skills and abilities (KSA) which managers need to possess in order to effectively participate in the information systems arena.
\end{abstract}

\section{Keywords}

Hybrid managers, conversion courses, information technology, IT, education

\section{INTRODUCTION}

During the past decade it has become more and more obvious that managers, both within industry and the administrative sector, must become more IT literate if they are to perform effectively. They must acquire a range of knowledge, skills and abilities (KSA) which are associated with IT so that they can both use the products of IT and participate in the specification, design and development of new systems. The computer is no longer the preserve of a remote and separate IT or Data Processing department. It has become an essential tool which all managers must use effectively.

Hybrid managers (those who have both the KSA associated with their particular specialised areas and those associated with IT) are a key acquisition for any organisation. Within the UK one approach has proved very effective in providing existing and future managers with the KSA associated with IT. This is through masters level courses in computing which provide a "conversion" route into IT. 
At the university of Sunderland we offer an MSc Computer based Information Systems which is an IT conversion course for graduates, or equivalently professionally qualified personnel, who have little or no existing computing experience. The course is distinctive in that it is offered, not only in the UK but world-wide, in full time and part time study modes. In particular the various part-time versions of the course provide opportunities for existing and future managers to acquire and develop a wide range of KSA associated with IT. The course culminates in each student undertaking a significant IT based project normally related to their current place of work. Via the course they not only gain KSA associated with the specification, development and use of IT systems, but perhaps more importantly, they gain the ability to converse and deal with IT specialists in a meaningful and effective way.

In section 2 of this paper we discuss the need for hybrid managers and the KSA they should possess. In section 3 we then outline the role of MSc 'conversion' courses in supporting the education of hybrid managers and we give details of the structure, aims, development and operation of the MSc in Computer Based Information Systems at the University of Sunderland. We then proceed in section 4 to provide some case study examples of students who have successfully completed the course and become hybrid managers. Finally, in section five we present our guidelines regarding what managers really need to know about IT.

\section{HYBRID MANAGERS}

Alignment of information systems with business needs has always been of paramount importance and it is clear that in achieving this there is a need for people who understand and can operate effectively both within the business and IT areas. Moreover many authors, for instance (Laudon and Laudon, 1996, pxxiii), have emphasised that information systems have become so vital to the management, organisation, operation and products of large businesses that they are too important to be left only to the technicians. The concept of hybrid managers and the key role that they should play within an organisation was initially identified by Michael J Earl (1989), director of the Oxford Institute of Information Management at Templeton College. Hybrids, according to Earl, are "people with strong technical skills and adequate business knowledge, or vice versa....hybrids are people with technical skills able to work in user areas doing a line or functional job, but adept at developing and supplementing IT applications ideas", (Skryme and Earl, 1989). The British Computer Society (BCS) felt that this type of manager was of such importance to British industry that they set up a task group to investigate and promote the concept. This resulted in the publication in 1990 of the report "Hybrids: From Potential to Reality" (BCS, 1990) which showed that industry was very positive towards the concept of hybrids and predicted that by the middle of the decade the UK would need some 10,000 hybrid managers if it was to compete successfully.

Hybrid managers have been identified (Skyme and Earl, 1990) as not only requiring information and business knowledge but also organisation specific knowledge, group managerial skills and pertinent personality traits. The latter they have summarised as being: outgoing, people oriented, catalytic and visionary, in fact the reverse of the stereotyped introverted computer specialist! 


\section{UNIVERSITY OF SUNDERLAND'S M.Sc. IN COMPUTER BASED INFORMATION SYSTEMS}

It is obvious that there are two distinct ways in which educational institutions can assist in the production of hybrid managers by means of M.Sc. level "conversion" courses. The first is by providing IT specialists with business and managerial skills and the second is to provide existing managers with IT skills. In the remainder of this section we describe the University of Sunderland's MSc course in Computer Based Information Systems which we believe provides an excellent example of this latter approach. The course is distinctive in that it is offered in five different delivery/learning modes:

- Full Time over twelve months at the University,

- Part Time Evening over 33 months at the University,

- Part Time Day over 24 months at the University,

- Block Mode over 36 months where formal attendance at the University is restricted to a maximum of four weeks per year,

- Distance Learning Mode supported by in-house produced videos and related textual material. This mode is offered from approved centres both within the UK and internationally.

\subsection{Course structure and its aims}

As stated previously the MSc/PGD/PGCert in Computer Based Information Systems is a "conversion" course for non-computing graduates who are interested in gaining a theoretical and practical understanding of the construction of computer based information systems. The course has a modular structure and operates within a Postgraduate Credit Accumulation and Transfer Scheme (CATS). The course consists of two main elements: a taught element (which has a value of 70 CATS credits at level $M$ ) and an externally sponsored project (which has a value of 50 CATS credits at level M). Intermediate awards of Postgraduate Certificate and Postgraduate Diploma are available for students who wish to leave the course during or at the end of the taught part having gained 35 or 70 credits respectively.

The aims of the course are to:

- promote a critical awareness of the natures, roles and limitations of computer based information systems,

- develop the knowledge, skills and understanding needed to specify, design, implement, document and furnish continued support for an effective computer based information system, either alone or as part of a team.

- allow the student to consolidate and display skills, knowledge and awareness in a selected application area for computer based information systems and gain experience of implementing such a system.

A major part of the course is an externally sponsored project to which the student is expected to devote at least 540 hours of work. The aim of the project is to extend and develop the student's ability to analyse, specify, design, implement and document an effective computer-based information system which satisfies an organisational need. The undertaking of the project should mean that students will be able to demonstrate their ability to:

- Plan, schedule, monitor and control the conduct of a substantial piece of research and development work 
- Select and critically assess relevant material from original papers and articles, and to extend the lines of research therein

- Apply some of the methodologies developed during the course

- Plan and communicate, both orally and in writing, a programme of work in information system design and implementation.

\subsection{Course development and operation}

In the late 1980's the UK Department of Employment, through its Training Agency, launched a programme known as "High Technology National Training (HTNT). This was a programme of "intensive, professional level, occupational training in high technology skills which are in demand in the national labour market" (Training Agency, 1989). Discussions between the, then, Sunderland Polytechnic and the Training Agency in early 1989 led to the School being awarded funding to mount a full time MSc in Computer Based Information Systems.

The course was designed to meet the real market needs identified by the HTNT programme, it was validated on 18th September 1989, and commenced with its first cohort of 50 Training Agency funded students on 25th September 1989. Two further cohorts each of 60 students were funded in the following two years under the HTNT programme (the maximum time span allowed). During this time the operation of the programme was devolved to local Training and Enterprise Councils (TECs) since the Training Agency was replaced by the Training, Enterprise and Education Directorate. The close links formed with the Wearside TEC (now Sunderland TEC) and the success of the full time course have helped the School to gain further funded places during the last three academic years via schemes supported by the European Social Fund (ESF) and the Departments of Employment's Training For Work scheme (TFW).

\section{The redesign of the part time evening course}

A part time course had existed prior to 1989 but with a different structure from that of the full time course validated in September 1989. There had been several problems with both the content and operation of the part time course, which naturally were taken into account when the full time course was developed. In 1990 the part time course was completely redesigned to meet the changing needs of industry; therefore, the full time course's syllabus and its structure were used as a base. The part time course is delivered over three years. Years one and two cover the taught elements and are given on two evenings each week each for three hours. The third year of the course is devoted to the project, which is normally sponsored by the student's employer. Different arrangements for the delivery of the taught part of the course have been tried over the years. The most effective has been to run two subjects in parallel for the first half of the year and then the other two in parallel for the second half.

\section{Modularisation and the block mode}

In 1992 a rationalised modular course was developed within a CATS framework; this incorporated the Full Time, Part Time and a new delivery mode, Block Mode. These developments were the results of recognising changes in customer needs. Students wanted more flexible learning opportunities: the ability to transfer from full time to part time study if a job opportunity arose was seen as a major benefit by full time students. It was also recognised that evenings only part time attendance did not suit many students (or their 
employers). There were two advantages to be gained from offering the course in a Block mode: firstly local students were offered greater flexibility in study patterns and secondly the course was then also available to students from outside the region.

The Block mode is also a three year part time course. However, the central feature of its delivery is that the taught material, which is covered in 120 three hour evening sessions on the conventional part time course, forms eight blocks each of which is a residential teaching week of 45 hours duration. These residential weeks are spread over a two year period and each taught module is supported by distance learning materials both before and after the relevant residential week. These weeks are held outside the normal undergraduate teaching year and thus there is no conflict over the allocation of resources.

\section{Distance learning mode}

In 1992 it was recognised that the School had a mature course supported by material suitable for different forms of learning. It was also recognised that there was a clear market for this type of conversion course outside the UK. In particular, a demand was identified in both the far and middle east. Basically, the course material existed but many potential students could not attend the University despite the existing three flexible modes of learning. The fourth mode of the course was thus developed. This drew on the distance learning material developed for the Block mode but beyond that the decision was taken to produce videos in-house which would record the lecture material. The contents of these videos are presented by the staff who lecture on other modes of the course. The operational form planned for the Distance Learning mode of the course is that the videoed lecture material will be viewed at local, approved, study centres where a local course tutor would be present to discuss the material in the lecture, answer questions from the students, and oversee practical work. Moreover, "summer schools" at the local centre run and attended by staff from the University will provide the students with the opportunity to carry out in-depth practical assignments and communicate with the lecturers in person.

\section{Part time day}

As a result of interviewing potential students over the years our attention was drawn to the fact that there were two other groups who could benefit from the course. The first was those who have substantial family commitments and who, on the one hand could not devote sufficient time to the full time mode, and on the other could not commitment themselves to attending two evenings per week at the University. The second group consists of those who are in receipt of state benefits and who are currently looking for work. For these two groups the "part time day" mode of the course was initiated in 1995. This version of the mode allows students to complete the course in two academic years.

\section{CASE STUDIES}

In this section we provide details of three typical students who have completed the part time version of the course and by doing so have become successful hybrid managers.

\subsection{The librarian}

This student completed the course in 1990 . When she began the course she was a faculty librarian in an academic library with responsibility for a staff of one. Her knowledge of computing at that time was simply as a user of existing automated library systems. The 
practical element of her M.Sc. project was the development of an expert system and she believes that the course both broadened her knowledge of computer systems and has given her confidence in working with them and technical computing staff. She now holds a major management role within an academic library and has responsibility for $27 \mathrm{staff}$. In addition to her normal role she recently acted as the IT development officer for the entire library for a period of five months, during the absence of the postholder. She headed the team who were responsible for installing a CD ROM-based information system across her institution. She also now teaches about electronic information sources across the institution.

\subsection{The accountant}

This student is the site accountant for a large multinational manufacturer which has one of its factories in the North East of England. He completed the course in 1995. When he started the course he already had some experience in the use of PC packages and had produced his own spreadsheets. He had also been involved, as a user, in the determination the requirements for some mainframe based systems. His project was concerned with an indepth investigation of how the use of spreadsheets had impacted on companies' financial systems. The student is very positive about the skills the course has given him and the highlighted the following:-

- He now has a more professional approach to the production of computer based financial systems: this includes ensuring there is consultation with the recipients of the systems' output (accounting reports for non-accountants)

- His role has expanded to include a responsibility for IT systems in the factory.

- He has become the internal consultant for Microsoft packages.

- He has gained skills which allow him to cope with the demands for more and more information being demanded in a shorter time span.

- He has significantly improved his ability to discuss IT problems with the company's MIS staff.

\subsection{The engineer}

This student also completed the course in 1995. When he began the course in 1992 he was employed as an electronics technician in the engineering department at an installation owned by a very large multinational company which specialises in home consumer electronic equipment. His computing knowledge was very limited and was related to the use of machines to control activities on the shop floor. His project centred on the benefits of work group computing and he implemented a small pilot PC network at his installation. He believes that he now has substantial skills in the area of work group computing and the development of computer networks. This belief is confirmed by the fact that he now holds the post of computer systems supervisor in the site's IT department (equivalent to computer manager). The course has been fundamental in progressing his career and has given him "an excellent understanding of a wide range of IT areas from software and hardware procurement to data base design and development".

\section{CONCLUSIONS}

The case studies presented above illustrate the success of our course in producing managers with hybrid skills. In a recent review of the course content we have paid 
particular attention to the needs of those who will not enter the mainstream of computing but who will need a much broader ranger of IT skills so that they can operate as hybrids. The modules within the taught part of the revised course are:

$\begin{array}{ll}\text { Computer and Research Skills } & \text { (10 credits) } \\ \text { Application Building } & \text { (5 credits) } \\ \text { Systems Development } & \text { (10 credits) } \\ \text { Network \& Computer Hardware } & \text { (5 credits) } \\ \text { Software Environments } & \text { (5 credits) } \\ \text { Object Orientation } & \text { (10 credits) } \\ \text { Relational Database Systems } & \text { (5 credits) } \\ \text { Systems Engineering } & \text { (10 credits) } \\ \text { Applied Knowledge Engineering } & \text { (10 credits) } \\ \text { Software Construction } & \text { (10 credits) }\end{array}$

The last two modules are identified as optional as students select whichever is more applicable to their career aspirations.

Finally as our guidelines regarding what mangers really need to know about IT we simply present the learning outcomes for our revised course. Which are that on completion the student will be able to:

- discuss the nature, role and function of computer-based information systems in organisations

- be familiar with different software and hardware platforms

- analyse information system needs and formulate systems requirements

- specify, design, implement and document a computer-based information system, using high level language and appropriate tools, which are technically, professionally and economically acceptable

- understand why and how to apply a professional engineering approach to software construction.

- exhibit sufficient critical awareness of current technologies to be able to implement and support distributed computer-based information systems

- understand the fundamental concepts of, and be able to use, system software environments

- describe the principles and operation of the components of a distributed information system

- select, research and critically assess relevant material from original papers and articles, in order to plan, schedule, monitor and control the conduct of a substantial piece of research and development work culminating in the production of a computer-based information system

- communicate, both orally and in writing, a programme of work in computer-based information system design and implementation

- understand and use the object oriented paradigm

- exhibit knowledge and skills in Knowledge Engineering

- design and fabricate software products using a low level programming language.

This paper stated that there are two ways in which hybrid managers can be developed. We have concentrated on illustrating how those with existing management skills can benefit from having the IT dimension grafted to their skills base. It is worth noting however, that within the University of Sunderland we also address the needs of the second group: IT 
professionals. Often these professional have not received formal education and training to equip them with the knowledge of the theories and management skills that need to be applied by successful hybrid managers. For this group our M.Sc. in Management of Information Technology complements their existing skills and provides those managerial KSA.

\section{REFERENCES}

British Computer Society (1990) Hybrids: From Potential to Reality. BCS Task Group Report, Swindon, England.

Earl J.S. (1989) Management Strategies for Information Technology, Oxford University Press, Oxford, England.

Laudon, K.C and Laudon J.P. (1996) Management of Information Systems: Organisation and Technology. 4/E, Prentice-Hall, New Jersey,

Skyrme, J.S. and Earl, M.J. (1990) "Hybrid Managers": what should you do. The Computer Bulletin, May,19-21.

Training Agency (1989) High Technology National Training: The National Programme Prospectus. Department of Employment, Sheffield, UK.

\section{BIOGRAPHY}

Barrie Thompson is Professor in Applied Software Engineering at the University of Sunderland. He is also programme co-ordinator for the five different modes of the University's MSc in Computer Based Information Systems.

Helen Edwards is a senior lecturer at the University of Sunderland and also holds a doctorate in computing. She is course leader for the full-time mode of the MSc in Computer Based Information Systems at the University. She has previously been course leader for the part-time version of the course and admissions tutor for all versions of the course run at Sunderland. 